\title{
INDUSTRIAL OWNERSHIP IN ALBANIA: TRADEMARKS
}

\section{MSc.Anjeza Dajzmaili}

Lecture/Lawyer of Intellectual Property

The term of industrial property in Albanian legislation, it refers to a complex of institutes that have the function of guarantee to the distinctive signs of entrepreneurship and the intellectual creation with technological content.

\subsection{The concept of trademark in Albania legislation}

Trademarks are signs that can distinguish goods or services that produce or give a subject, from those of another subject. As a trademark can serve: words, combination of letters and numbers, logo, drawing, color, wrapping form, etc. Generally, as a trademark may serve any sign that can be presented graphically, through lines and figures ${ }^{1}$. There are countries that allow the registration of so-called "invisible" trade such as those of voice or the fragrance of a product.

(the first registration is also allowed in our country).

In any case it should be a perceptible sign with at least one of the senses. In fact, the Industrial Property Law is limited to several aspects that we can summarize at several points:- "Brand Right" is provided in Article 144 of the Law, which regulates the cases of legal protection of a mark. The right to seek protection from the law on industrial property it has every subject that is registered by the manners prescribed by the law of a distinct brand or services, by earning the exclusive right to the product or service acquired. This means that the right to a trademark has any entity that registers its trademark before the DPPI institution ${ }^{2}$. In the absence of registration, Albanian legislation does not grant the right to protection. Does Albanian legislation protect a brand that has years in the market but has not been registered under the applicable law? The answer to the question is given in Article 144.

1 Article 140, Law Nr.9947, date 7.7.2008 Industrial Ownership Law.

2 Article 144, Law Nr.9947, date 7.7.2008 Industrial Ownership Law. 
Specifically, if we take the case of a brand that has been operating in the market for years but has not been registered in the form required by law and another brand with similar products or services is marketed and is registered according to the

form required by the law, if so the latter is protected by the Albanian legislation. And a trademark that is not registered under the law regulations does not have any kind of protection either by civil code.

Otherwise, it occurs in Italian legislation (Article 2571 of the Italian Civil Code) ${ }^{3}$, where a subject has an unregistered trademark he has the right to continue to use it, although other commercial entities are registered in the form required by law.

According to Italian legislation, the protection of the trademark in cases where the subject has not registered with the relevant institution is protected by Article 2571 of the Italian Civil Code. This article protects all those brands, which are in the market but are not registered in the form required by the law on industrial property and precisely because they have acquired a name from the consumer Italian legislation recognizes the right to use protection.

So even though a new brand to the market is similar to an existing but unregistered brand, the first one cannot hinder the operation of the unregistered brand market.

In Albanian legislation this case is not granted, but if we make a narrow interpretation of Article 144 it is understood that the registered mark enjoys the right of legal protection and consequently the right to prevent a similar brand that is earlier in the market but which is not registered.

- "Collective Brand" is foreseen for the first time in Albanian legislation by the Industrial Property Law. Under current law, specifically Article 165, collective marks mean those marks by which brands of goods are distinguished or serviced by any association or form of collective legal arrangement ${ }^{4}$.

Some co-partners require a collective mark for a production or service they provide under the applicable law. The collective brand is a brand totally different from the individual brand, where the latter is intended to distinguish the products or services of a venture from another venture into competition.

To better clarify Article 165 of the Industrial Property Law, let's give some examples:

3 Italian Civil Code, Article 2571 "Preuso".

4 https://www.laleggepertutti.it/codice-civile/art-2570-codice-civile-marchi-collettivi. 
- BANCOMAT: is a collective brand that is used by many companies as an agreement that respect the regulations set by the trademark holder at the time of the deposit.

- GRANA PADANO: It is a famous brand known for its high quality Italian cheese. This brand can only be used by companies that follow a rule on how to produce cheese to be in the standards of this brand and they can only use the brand of Grana Padano ${ }^{5}$

So, as explained in the above examples to register a collective brand together with the application, a regulation should also be filed that determines who the mark may be used and what are the necessary criteria that the product should have to be part of this mark. The regulation is drafted to the trademark holder who may be a public entity or a private entity. These types of trademarks also run the warranty function for customers by buying a product or service that contains some features that is distinct from others. For this reason, the collective brand is a certified guarantee brand. But also the collective mark differs from the individual mark for how the registration is made and the criteria that must be met at the time of filing the application. Because for collective trademark registration it is much more complex than for individual brands because it asks for registration the introduction of a regulation that disciplines the use and clarifies the rules on the control that the trademark holder must perform to ensure that the regulation will be respected Sickness cases will apply to entities that do not respect them.

- "Opposition to a trademark" 6 under Albanian law may be claimed by the applicant of a previous trademark, the owner of a trade name, a natural person, the owner of a prior industrial property right, any person who has the right to Authorized Users of Certification Marks, or Brand Licensors by the Brand Owner. The registration of a trademark allows its holder to exercise exclusive rights only to his own products. The Brand User (Seller of Products) has the obligation not to compromise the manufacturer's trademark.

5 Clemente Tartaglione, Fabrizio Gallante, "Il marchio nella strategia di sviluppo delle imprese moda", Ares 2.0, Rome, 2009.

6 Article 152, Law Nr.9947, date 7.7.2008 Industrial Ownership Law. 
- Reinstatement in time of the right ${ }^{7}$ - In all cases where, in the absence of the applicant's will for mark registration, a situation is created which directly causes the refusal of the application for registration of the mark, the law in Article 151 / c provides for the right applicants to request resettlement within a period of not later than 2 months from the occurrence of obstacles that have caused the refusal of the trademark registration and not later than one year from the date of expiry of the lost time limit.

Restitution on a deadline is a right that is valid as long as the law permits because after the expiration of the legal deadlines it loses the right to register the trademark. However, at the moment when it exercises the right to resettle in time and it is accepted by the Industrial property institution then the legal consequences caused by disrespect of time shall be deemed not to have occurred.

- Ownership transfer of a mark- The mark may be transferred or leased in whole or in part a part of its products or services for which it is registered until in any case by the transfer or from the license there is no inaccuracy or deception of the type product or service that are in the customer's assessment. When a trademark is made up of a figurative mark or a sign of fantasy or another branch, it is assumed that it's exclusive right to be transferred together with the enterprise.

In order to regulate competition between undertakings and to ensure their recognition in the market, the legislator has foreseen some legal provisions on distinct signs. We can share them in signs; (or otherwise known as distinct typical signs), but these provisions also apply in case of symbols created specifically by the entrepreneur (such as advertising panels, online domain name or slogan (where the latter are called atypical signs).

Undoubtedly, all typical and atypical signs perform an important function because they contribute to customer orientation by establishing the formation and preservation of the clientele $^{8}$. Certainly, the lawmaker has taken into account the legal protection of the entrepreneur's interest:

- Being free to choose distinctive signs

- Exclusive use of signs

- Giving it the ability to transfer it.

7 Article 151/c Law Nr.9947, date 7.7.2008 Industrial ownership Law.

8 Gian Franco Campobasso, Manuale di diritto commerciale, UTET Giuridica, 2017, fq 34-56. 


\subsection{The juridical nature of distinctive signs}

Regarding the juridical nature of distinctive signs is in an open debate on the doctrine, which is divided into two concepts:

1. That distinctive signs can be included in the category of intangible goods even if they are not entirely intellectual creations; the entrepreneur enjoys a right of ownership over them 9 (authors Santini, Ascarelli).

2. Distinctive signs have autonomy and are not immaterial good. The overwhelming person enjoys no right over them because they are directly related to the product or service they offer.

The brand is a sign or symbol that can distinguish, within a range of products or services, those that come from a particular business.

The brand has distinctive function and reference function on the product or service of entrepreneurship. It is distinguished from typical "firm" signs, where it only distinguishes the entity, while the brand is able to distinguish a variety of (a bunch of) products within a range of other wider products. It also distinguishes itself from the "symbol" that approaches many brands that differentiate the location of the company, where it may appear to be numerous.

It is also worth mentioning the appealing feature of the brand, which is related to the businessman's interest in its registration as an ability to distinguish its products from competitors but also preferred ones (such as known brands). This is very important on the topic of protection because it makes legally valid protection of the brand's function, in which the businessman has certainly made an investment to make his favorite products and as such these investments have to be protected (such as original wardrobe or perfumes).

\subsection{The legal function of a protected Brand}

The protection of distinctive signs ${ }^{10}$ responds to individual and collective interests. Among individual interests, distinctive functions and appealing brand functions are introduced, while collective interest highlights the brand's warranty function in terms of product quality assurance. This evidences that we have 3 key functions of the brand:

9 Alessandra Avolio, Silvia dell'Angello, Compedio di Diritto Commerciale, Simeone, 2009.

10 World Intellectual Property Organizations. (n.d.) What is a patent? Retrieved September 27, 2008,taken from: http://www.wipo.int/freepublications/en/intproperty/450/wipo_pub_450.pdf 


\section{Distinctive function}

2. Attractive function

3. Quality assurance function.

A first European Union intervention in the field of industrial law was in 1988 directives protecting trademarks. The owner of a trademark through industrial property law seeks to protect the trademark and characteristics of that service or product or, otherwise, protects the trademark from unauthorized use ${ }^{11}$.

Actually today, anyone can register a brand; they can even give the full or partial license rent for it. This means that the one who owns a trademark can allow another third subject to take for rent the trademark license.

The brand usage criterion is also provided in the law, which stipulates that in case the use of the registered trademark for 5 years it does not lose the right to be protected.

1. The trademark distinctive function according to Article 141 of Law No. 9947, dated 07.07.2008, on Industrial Property, is changed when the ordinary user distinguishes between a different number of goods and services by another number of goods and services same as the first, without eliminating their trade origin.

2. The appealing brand function strengthens even more the importance of a brand and its role in the market. Using a branded product or service creates a certain number of users on the market, of course thanks to the attractive features that it has offered on the market (such as service or product quality). Over time, the brand becomes an inexhaustible swing of its users; in this sense the brand enjoys an appealing feature that a title of a brand when it creates it needs to be considered.

3. The guarantee's operation ${ }^{12}$ relates to "market laws" for which, if the quality is reduced, the consumer's preferences on that brand diminish (or diminish) proportionally (The typical case of the guarantee function relates to the determination of territorial geography or origin of the product especially in that food which indicate a kind of quality level from the product coming).

11 Christopher Pappas, "Intellectual Property \& Copyrights Research Paper Covering Cases", Business Ethics, Law and Communication, 2008.

12 Sony Corp. of America vs Universal City Studios Inc. (1984). Retrieved October 23, 2008, fromEnfacto http://www.enfacto.com/case/U.S./464/417/. 
But even in this regard, it is predicted in the law to protect this function (of course to protect the collective interest) wherever a brand is capable of creating confusion or lying to the consumer ${ }^{13}$. Also, we clarify that the industrial property law prohibits the deterioration of the quality of the product or service that characterizes a brand. This argues that protecting collective interest does not consist solely in guaranteeing a constant quality of a product or service to a brand, but to enable consumers to knowingly choose about a product. The legal instrument in protecting these interests is the exclusive right, which is understood as a real or absolute right. 


\section{Conclusion}

Industrial property is one of the most important intellectual property institutes. In the Albanian legislation is an area, which is still not in the levels of European Union countries. The industrial property concept for the first time in Albania entered in 2009 with the Industrial Property Law, through which the General Directorate of Industrial Property was set up. In 2018, the legislation underwent significant changes, where the main focus was on specifying procedures for marking a trademark and deadlines. But the responsible institution, the Directorate of Industrial Property, has a lot of work to do.

One of the main problems is the lack of proper information of domestic enterprises on the importance of protecting a business. For this reason, the last few years both state institutions and European Union institutions are working precisely to sensitize entrepreneurs to protect their business by registering with DPPI. It is also a very important institute with regard to the income that it guarantees for the state budget, one more reason to give the institute the proper significance. 